\title{
Paying for Peace: The Impact and Limitation of Amnesty for Militants and Averting Further Conflict in Niger Delta, Nigeria
}

\author{
Deji Kalejaiye Omoshola, Norafidah Ismail, Ummu Atiyah Ahmad Zakuan \\ School of International Studies, Universiti Utara Malaysia, Sintok, 06010, Kedah, Malaysia
}

\begin{abstract}
From early 1990 to 2009, Nigeria's oil-rich Niger Delta region was engulfed in conflict between multinational corporations (MNCs) and restive youths (popularly called militants) over the adverse effects ofoil pollution on their environment, live and economy. To curtail the conflict, Nigerian government initiated an amnesty programme for the militants in June 2009. This paper examined the impact and limitation of the programme, and measures to avert further conflict. The study was conducted via content analysis of books, articles in journals, editorials, and in-depth interviews conducted in the Niger Delta region between December 2018 and June 2019. This paper detectedthat the amnesty programme has brought about fragile peace, but the propensity of violence resurging is high,because the prime issues that triggered the conflict remain unaddressed. To forstall further conflict, Nigerian government and the oil MNCs must eradicate environmental degradation and invest in human and community development. Should conflict such as the one discoursed in this paper occur in the future, Nigerian government may grant amnesty, but must avoid 'paying for peace' as such approach is unsustainable. Rather than spend to lure people away from violence, the root cause of the conflict should be addressed.
\end{abstract}

Keywords: Conflict; peace; multinational corporations; amnesty; oil; Niger Delta; Nigeria

\section{INTRODUCTION}

$\mathrm{N}$ igeria's oil wealth, located in the Niger Delta region of the country, has been a major cause of conflict between oil multinational corporations (MNCs) and their host communities for over six decades. Since Shell D'Arcy (the precursor of the present Shell Petroleum Development Company of Nigeria) discovered oil in Oloibiri in 1956, (Ogoniland in 1958, and in other communities afterwards), the drivers of conflictin the Niger Delta has ranged from resistance to land grabbing, environmental degradation, destruction of local livelihoods, inadequate compensation, and underdevelopment (Saro-Wiwa, 1994; Douglas et al, 2003; Watts 2004; Emuedo, 2010; Mai-Bornu and Ladan, 2020). On each of these issues of conflict, Nigerian government has mainly takenside with the oil MNCs as against the people. Government's protection of the oil MNCs operation was so fierce that the military wasdeployedto crushnon-violent protesters in Ogoniland in the early 1990s. The community experienced human rights abuses and wanton destruction of lives and properties (Osha, 2006; International Crisis Group,
2008). The hallmark of the repression was the execution of Ogoni frontline activist, Ken Saro-Wiwa and eight others by the Nigerian military regimein 1995 . This action transmuted the Niger Delta's simmering grievances into fierce militancy against the oil MNCs and Nigerian government (Ushie, 2013; International Crisis Group, 2008).

The militants operation encompass bombing of oil installations, kidnapping of oil workers for ransom, and oil bunkering; all of which destabilized the Nigerian polity and oil-dependent economy (Oluwaniyi, 2018; Adeosun, Ismail and Zengeni, 2016). Militant activities dropped Nigeria's oil production capacity to 900,000 barrels daily ( $30 \%$ of what actual production should be) in 2007 (Golden-Timsar, 2018).In the third quarter of 2008, over 300 persons were kinapped, more than a thousand were killed, and Nigerian government lost $\$ 23.7$ billion from attacks on oil facilities, sabotage and oil bunkering (Report of the Technical Committee on the Niger Delta, 2008). The oil MNCs also incurred loss. Between 2003 and 2007, Shell declared a net loss of US $\$ 10.6$ billion (Austine and Sunday, 2013). The oil MNCs, as a whole, lost US\$21.5 billion within the same period (Nwozar, 2010).

These socio-economic falloutsimpelled Nigerian governmentto introduce an amnesty programme in 2009, which many of the militants embrace.They surrendered their arms in exchange for benefits, including monthly renumeration and educational or vocational training in Nigeria and abroad. This paper considers Nigerian government's action of awarding the benefits law-abiding citizens are not enjoying to unlawful militants as 'paying for peace'.Year 2021 marks 12 years since the amnesty programmecommenced. This paper reviews the impact and limitation of the programme in stemming the tide of violence in the Niger Delta.Additionally, it explores measures of averting further conflict in the region. The investigationwas conducted via content analysis of books, articles in journals, editorials, and in-depth interviews conducted in the Niger Delta region between December 2018 and June 2019. Of significance, this paper exposes the intricacies of eradicating violence through non-violent means. Such exposition would assist nations undergoing similar situation in decision making. 
The rest of this paper is considered in this manner: the next section, section 2, discussed the environmental, socioeconomic and developmental attributes of the Niger Delta. Section 3 discoursedthe amnesty programme. In section 4 , the impact and limitation of the programme was examined. Section 5 explored measures of averting further conflict and 6 presented the conclusion.

\section{STUDY AREA}

Nigeria has over 200 million population, which is the most populous in Africa and the highest concentration of dark race globally. The nation has the largest oil and gas reserves in West Africa and produces over 2.4 million barrels per day in the Niger Delta region (Mai-Bornu and Ladan, 2020). Oil was discovered in Nigeria by Shell in 1956. Other oil MNCs, including Chevron, Mobil, Agip, Total, etc are operating in the Niger Delta today.The Niger Delta region is made up of nine out of Nigeria's 36 states. The nine states includesAkwaIbom, Cross River, Delta, Edo, Ondo, Abia, Imo, Bayelsa, and Rivers state.Oil explored in the nine states accounts for over 90 percent of Nigeria's foreign exchange earnings and about $80 \%$ of budgetary revenues (Mai-Bornu and Ladan, 2020; Adeosun, Ismail and Zengeni, 2016).

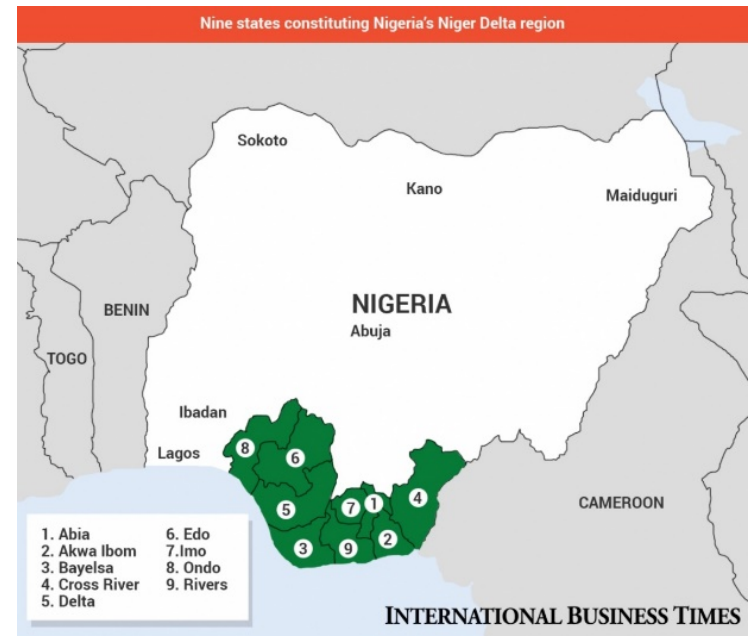

The people of the Niger Delta are ancestrally farmers and fishers. This impliesthat they solely depend on their ecosystem for survival, but incessant oil spills have degraded the lands and marines from which they source livelihood (Okonkwoet al, 2015; Kuenzeret al, 2014).Asidedegradation, Nigeria's Niger Delta region lacks every indices of development.Crucial infrastructures such as roads, hospitals, electricity, etc are either inefficient or unavailable.These challenges puts the oil-producing communities in conflict with the oil MNCs and Nigerian government. Scholars asserts that militancy in the region is a reaction to the repression, unemployment, underdevelopment, and near extinction of the environment and agricultural occupation that has sustained the people for centuries (Okeke-Ogbuaforet al, 2018; Omojimite, 2012; Ojakorotu, 2011).Ushie (2013) asserts that the amnesty programmeintroduced to address the crisis isNigeria's most prominent peacebuilding infrastructure since the nation returned to democratic rule in 1999.

\section{THE AMNESTY PROGRAMME}

Pursuant to section 175 of the 1999 constitution of the Federal Republic of Nigeria, President UmaruYar'Adua, on 15 June, 2009, granted "amnesty and unconditional pardon to all persons who have directly or indirectly participated in the commission of offences associated with militant activities in the Niger Delta" (FGN, 2009).Yar'Adua declared that the amnesty programme is government's contribution to "security stabilization in the Niger Delta region through the DDR programme, as a precondition for medium and long term development" (FGN, 2009). A new position of "Special Adviser to the President on the Niger Delta' was created in the Nigerian presidency to oversee the execution of the amnesty programme. The programme was to be operationalized via aDisarmament, Demobilisation and Reintegration (DDR) scheme illustrated below:

\begin{tabular}{|c|c|c|}
\hline Disarmament & $\begin{array}{c}\text { Demobilisation/Reha } \\
\text { bilitation }\end{array}$ & Reintegration \\
\hline $\begin{array}{c}\text { Duration: } 6 \\
\text { August to } 4 \\
\text { October } 2009\end{array}$ & $\begin{array}{c}\text { Duration: } 6 \text { to } 12 \\
\text { months }\end{array}$ & Duration: Up to 5 years \\
\hline $\begin{array}{l}\text { Collection of } \\
\text { arms, } \\
\text { ammunition, } \\
\text { explosives }\end{array}$ & $\begin{array}{l}\text { Ex-militants report to } \\
\text { camp }\end{array}$ & $\begin{array}{l}\text { Knowledge and skills } \\
\text { acquisition }\end{array}$ \\
\hline \multirow[t]{11}{*}{ Biometrics } & $\begin{array}{l}\text { Verification and } \\
\text { documentation }\end{array}$ & Financial empowerment \\
\hline & & Placement programmes \\
\hline & & Microcredit \\
\hline & $\begin{array}{l}\text { Transformational } \\
\text { training }\end{array}$ & Education \\
\hline & $\begin{array}{l}\text { Peacebuilding and } \\
\text { conflict resolution }\end{array}$ & $\begin{array}{l}\text { Reconciliation with local } \\
\text { community }\end{array}$ \\
\hline & Counselling & $\begin{array}{c}\text { Conflict resolution } \\
\text { framework/mechanism }\end{array}$ \\
\hline & Career guidance & $\begin{array}{c}\text { Monitoring and } \\
\text { evaluation }\end{array}$ \\
\hline & Wellness assessment & Exit from amnesty \\
\hline & $\begin{array}{l}\text { Reintegration } \\
\text { classification }\end{array}$ & \\
\hline & $\begin{array}{c}\text { Education and } \\
\text { vocational placement }\end{array}$ & \\
\hline & $\begin{array}{c}\text { Graduation and } \\
\text { demobilisation }\end{array}$ & \\
\hline \multicolumn{3}{|l|}{ Key enablers } \\
\hline \multirow[t]{3}{*}{$\begin{array}{l}\text { Disarmament } \\
\text { camps }\end{array}$} & $\begin{array}{l}\text { Transformational } \\
\text { training centres }\end{array}$ & $\begin{array}{l}\text { Partenering government } \\
\text { agencies, NGOs and } \\
\text { private organisations }\end{array}$ \\
\hline & Rehabilitation camps & $\begin{array}{l}\text { Oil and gas institutions } \\
\text { (OGIs) }\end{array}$ \\
\hline & & $\begin{array}{c}\text { Tracking and support } \\
\text { system }\end{array}$ \\
\hline
\end{tabular}

Niger Delta Amnesty Programme of the Federal Government of Nigeria (FGN). Sourced fromUshie (2013) 
The DDR is a potent means of reconciling conflict and managing post-conflict matters. It has been used by the United Nations and several countries toachieve sustainable peace. This made Nigerian governmentto adopt it for the Niger Delta amnesty programme (Ibaba, 2011). After the amnesty was declared, militants publicly renounced violence and surrender their arms and ammunitions to the security agencies. Records from the office of the Special Adviserto the President on the Niger Delta indicates that a total of 26,358 ex-militants, in two batches, have participated in the amnesty programme since 2009 (Ushie, 2013). The first batch, totalling 20,192 persons, were demobilised in 2009 , while the second batch, numbering 6,166 persons were demobilised in 2011. Both batch emergedfrom eight, out of the nine Niger Delta states. Abiastate did not participate as none of the residents owned up to beinga militant (Austine and Sunday, 2013; Ushie, 2013).

The 26,358 ex-militants received N3,000 (US\$8) daily allowance during the reintegration phase, and another N65,000 (US\$180) monthly (Okonofua, 2016). As observed in the table, one of the most prominent feature of the amnesty programme is its emphasis on educational, and vocational training (encompassing skills acquisition and entrepreneurial development) for the ex-militants. Akinwale's (2010) appraisal of the ex-militants career goals revealed they are mainly interested in working in eight sectors, which includes oil and gas; exploration, processing and production engineering; welding and fabrication technology; and maritime services.

The amnesty programme started in 2009 , and as indicated in the table, the total period of implementation of the DDR is about six years, hence the 26,358 ex-militants hasundergone all the phases of the DDR. In spite ofthis, the amnesty programme is still on as the ex-militants and Niger Delta leaders areprevailing on government not to end it.The exmilitants wants the programme sustained because most of them are yet to get a job or start up capital after training. They claim they are living on the amnesty's stipend and stoppage of it would push them into economic hardship. Backing the exmilitants claim, the political, religious and traditional leaders of the Niger Delta wantNigerian government to sustain the amnesty programme as ending it without meeting the needs of the ex-militants could revive violence.

\section{IMPACT AND LIMITATION OF THE AMNESTY PROGRAMME: A REVIEW}

Ogege (2011) argues that the amnesty programme is government's deceitful antics to calm restive youths and pave way for unhindered oil operations, while crucial issues of degradation and underdevelopment remain unaddressed. In agreement, Aghedo (2012) contends that even though the amnesty programme somewhat eased the conflict between the oil MNCs and their host communities, peace remains subtle as the Niger Delta region is in a 'no-peace, no-war' situation. Sustainable peace can only manifest when: (1) the motivations for hostility are identified and addressed; (2) when underdevelopment and environmental insecurity are tackled; (3) when people who have suffered psychological and physical damages are compensated; (4) when extra-judicial killings and human rights violators are prosecuted and; (5) when Nigerian government increase the revenues allocated to the nine oil-producing states (Aghedo, 2012).

Avowing that the amnesty programme ignored the cause to focus on symptoms of militancy, Ogege (2011) asserts that for lasting peace to be attained, Nigerian government must: (1) desist from favouring the oil MNCs at the expense ofthe peoples welfare; (2) improve on stakeholders consultation and participation; (3)efficiently rehabilitate the ex-militants; (4) focus on youth employment through creation of small scale industries; (5) ensure fair allocation of revenues; and (6) create a holistic framework for the development of the Niger Delta and implement it.

Appraising the effectiveness of the amnesty programme, Eke (2014) contends that when multiple petitions and non-violent protests yielded no positive result for the people of the Niger Delta, violent agitations evolved and militants began to profit from the conflict, butthe amnesty has calmedthe restiveness. In agreement,Ubhenin (2013) posits that the threat the militancy posed to Nigeria's economy and national security impelled government to initiate the amnesty programme. Buttressing the claim, Eke (2014) asserts that oil production, which dropped to 1.4 million barrels per day during the militancy rose to 2.2 million after the amnesty was initiated (Eke, 2014).Of one mind, Ogege(2011), and Ajayi and Adesote (2013) proclaimed that the amnesty programmehas brought about relative peace andan appreciable boost in oil production.

Assessing the amnesty programme's impact on peacebuilding, Ekumaoko (2013) asserts that the programme is a credible path to peace, but not an end in itself. The scholar argues that the negative peacethe programme has created is making government feelrelaxed and accomplished. So longas the programme enables unhindered oil exploration by the MNCs, Nigerian government would continue to wrongly think thatadequate security and peace has been achieved(Ekumaoko, 2013). In agreement,Ajayi and Adesote (2013) posits that the amnesty programme is a short-span functional approach that cannot comprehensively address the environmental and developmental problems of the Niger Delta. Calling for overhaul, Ekumaoko (2013) warns that the amnesty programmemay collapse and such would have a catastrophic effect on national income and security.

Evaluating the DDR strategy's potency to curtail militancy in the Niger Delta, Agbiboa (2015) asserts that the amnesty is a non-killing approach to eradicatinginsurrection; a means of 'bribing' the militants so that the oil MNCs can operate unhindered. Doubting the amnesty's potency to achieve peace beyond the short term, Okonofua (2016) argues that the programme was tactically instituted to: (1) save Nigeria from 
sliding deep into socio-economic confusion; and(2) erase the oil MNCs fear of being attacked. Okonofuastated that the amnesty programmehas restored fragile peace in the onshore, while offshore sabotage and violence are still being perpetrated by some of the militants who embraced the amnesty, those who rejected it, and thosethat emerged after the programme was launched. Okonofuawarns that the probability of violence re-erupting is very high. Should that happen, the 'repentant' militants would return to their rebellious acts; thinking government would call for dialogue and pardon them again (Okonofua, 2016). This argument gives credibility to Agbiboa's (2015) assertion that government's patronage has wrongly signalled the youths that rebellion and militancy is rewarding. His assertion ratifies Aghedo (2012), and Ajayi and Adesote's (2013) argument that the amnesty programme has not provide satisfactory solution to the Niger Delta conflict, rather, it portends fresh threat to peace and renewed hostility due to the lop-sidedness and youth-focused approach that ignores the rest of the populace.

Eke (2014)asserts that Nigerian government's failure to commit to sustainable development would resurrect the conflict. The rising post-amnesty unrest in the Niger Delta is proving Eke right.Agbiboa (2015) proclaims that the death of the amnesty initiator, late President UmaruYar'adua, led to a wreck in the programme's rehabilitation and reintegration, such thatthe ex-militants are complaining of: (1) irrelevant and inadequate training; (2) delayedremuneration; and (3) mismanagement of their allowances by their commanders who are already earning huge fromthe pipeline protection contracts awarded to them by government. Consequently, some of the short-changed ex-militants have chosen to makea fortune from oil theft, even while still participating in the amnesty programme (Olaniyi, 2011). Agbiboa (2015) proclaimed that 80 percent of the amnesty programme's fundwere used to hire consultants, administrators and ex-commanders, leaving an insignificant 20 percent for the ex-militants' rehabilitation.

Agbiboa's (2015) revelation ratifies Olaniyi's (2011) assertion that "the amnesty programme is not a transformational strategy, but a lucrative business" (pg. 52). Also, Eke (2014) posits the amnesty was a "cash for peace" programme; which triggered more violent demands from those seeking to have a taste of the 'national cake'. Warning that the amnesty may distract attention from the core issues of peace, security and development, Hinshaw (2012), who is an ex-mediator for government,asserts that 'everyone appears to think the Niger Delta crises is over, but it is just on pause, the main task is to progress from pause to stop'.

Examining the amnesty programme's effectiveness against the recurrence of kidnapping for ransom in the Niger Delta, Aghedo (2015) posits that while the programme have significantly reduced the resentmentbetween the militants and Nigerian military, violence has been promoted by government's resolve to reward those who committed heinous crimes against the state. The scholar reveals that through kidnapping, someof the rebellious youths (militants) became millionaires to the envy of the non-rebellious ones, who are now also going into crimes such as kidnapping, piracy and oil theft. Aghedo affirms that themain complaints that triggered the militancy, such as widespread poverty, marginalisation, environmental degradation and unemployment still persist and continues to propelconflict. Condemning the 'excess' devotion of energy and resources to the amnesty programme, Ubhenin (2013) advocates for anabolition of the Nigerian 'rentier' system. In contrast, Aghedo (2015) advice government to desist from enriching individuals via the amnesty programme, and focus on infrastructural development. He argues thatsuch action woulderadicate violence as everyone -- rather than a class of people -- would benefit from the development.

Assessing the credibility of the amnesty programme, Ajibola (2015) proclaims that the inclusion of educational and vocational skills acquisition in the programme is helpful for youth transformation and crime reduction. He however stressed that adequate post-amnesty employment opportunity ispivotal to the overall success of the programme. In high hopes, Ajibola argues that if proper structures are put in place, the ex-militants would transform into agents of change and collectively work towards the attainment of peace and development inthe Niger Delta. To the mind of the authors of this paper, Ajibola's assertion undermines the complexity of the Niger Delta situation by ignoring or failing to acknowledge that it would be difficult to transform majority of the ex-militants into progressive citizens because they are used to living extravagantly on crime.

Before embracing amnesty, the ex-militiants daily routine revolves around smoking; consuming hard-drugs and alcohol; buying and selling dangerous weapons; perpetrating violence; and making an outrageous 'free' money from oil theft. Ajibola failed to come to terms that it would be difficult for the 'repentant' militants to desist from their dishonourable acts and lavished lifestyle. Upon completion of their educational and vocational programs, the ex-militants would find it uneasy to surivive on wages lower than what they were earning from oil theft, artisanal refining and kidnapping. Ajiboladid not fathom that the profitability of crime has a high potency of luring the ex-militants back to crime, regardless of how much they are pampered or persuaded not to. This will hinder the realization of peace and development.

Oluyemi (2020) examines the impact of military operations in the Niger Delta conflict and discovered that the operations were "terrifically counterproductive." The scholar denounced the deployment of military to stem environmental and economic insecurities. He calls on government to equip the police and "expand the agenda of security beyond the military" in the interest of Nigeria's democracy. Examining communal perceptions about the existence and causes of structural violence, Okeke-Ogbuaforet al (2018) asserts that structural violence manifests in both visible and invisible forms. Elites blamed the violence on exogenous factors, while the masses blamed it on exogenous and endogenous factors. 
Both factors can be exterminated by reducing inequality and increasing democratization (Okeke-Ogbuaforet al, 2018).

Examining the relationship between oil production, grievances and attitudes towards anti-state violence in the Niger Delta, Koos (2017) argues that collective grievances (such as unfair distribution of oil revenues) and individual grievances (such as destruction of livelihood by oil spills) are causing people to support anti-state violence despite the amnesty. Examining the factors influencing and shaping community perceptions of oil MNCs in the Niger Delta, Oderaet al (2018) argues that poverty, environmental degradation, and destruction of cultural, emotional and spiritual valuables such as land have created a negative perception of the oil MNC. Thus, to operate successfully in the Niger Delta, beyond amnesty, the oil MNCs must strive to build a cordial relationship with their host communities by taking up socially and environmentally responsible practices (Oderaet al, 2018).

The review done so far highlights that the amnesty programme has a major impact of reducing the spate of violence in the Niger Delta, and a major limitationof not being a sustainable path to peace. In the next section, we discourse measures of improving the efficiency of the amnesty programme and averting the resurgence of militancy.

\section{AVERTING THE RESURGENCE OF VIOLENCE}

The amnesty programme has prompted a decline in hostility, but the plights of the Niger Delta people -- particularly their demand for an end to environmental degradation and underdevelopment -- remains unaddressed(Aghedo, 2012; Mai-Bornu \&Ladan, 2020). Although the reduction in violence has paved way for Nigerian government and theoil MNCs to accruemore profit, nothing significant has been done to eradicate the plights of the oil-producing communities. Theinhabitants cannot endure this for long, therefore Nigerian government mustswiftly address their grievances to prevent a resurge of violence. If theirgrievances are not promptly addressed, in a matter of years, another round of hostility would emerge, and by then, 'paying for peace' may no longer be effective,just as theapproachpreceding it(repression) is ineffective today.

Nigerian government's failure to establish a systemic means of providing social goods and services is decreasing the efficacy of the amnesty programme. Socioeconomic ills such as lack of infrastructure, poverty, unemployment and inequality are endemic in the Niger Delta. These ills are brewing communal disenchantments that may erode the fragile peace the amnesty has established.Some of the displeased populace would overtime emerge as (new) militants, even if the repentant ones do not return to violence.Ajayi and Adesote (2013) argues that "only development can ensure lasting peace in the Niger Delta region, therefore a robust development agenda that will tackle unemployment, degradation and socioeconomic underdevelopment must be formulated and implemented swiftly" (p. 518). Indeed, some form of comfort - such as provision of portable water, electricity, etc - must be provided and gradually improved on for peace to persist in the Niger Delta.

Aside addressing the people's socio-economic challenges, Nigerian government mustaddress the shortcomings of the oil MNCs.There has been no significant change in the modus operandi of the MNCs despite persistent oil spills.Oil bunkering, which is a major source of oil spills is also gaining prominence because there isnoreprimand or incentives to discouragepeople from the act. Lack of commitment to eradicate environmental degradation (Okeke-Ogbuaforet al 2018; Nwozor, 2019; Mai-Bornu \&Ladan, 2020) which would give live back to the people is making illegal means of survival, such as oil bunkering and artisanal refineringrampant in the Niger Delta.

Oil bunkering must be eradicated, otherwise several vulnerable persons would embrace the act due to its profitability. Nigeria is losing over 300,000 barrels of oil to illegal activities in the Niger Delta daily (Campbell, 2015; Oluyemi, 2020). This loss is more than Ghana's total daily production of 120,000 barrels per day (Ushie, 2013). Nigeria's over 300,000 barrels per day loss is about $15 \%$ of the nation's daily production of 2.4 million barrels. Fiscally, the loss amounts to over $\$ 1.7$ billion monthly (Campbell, 2015) and $\$ 42$ bn in the last decade (Hazardex, 2019). The loss is mainly sold to artisanal refiners in Nigeria and neighbouring nations, including Benin Republic, Cameroon and Cote d'Ivoire (Human Rights Watch, 2003). The funds accrued from the illicit trade is not only being used for pleasure, but also for arms purchase. Eradicating oil bunkering would reducethe influx of arms, otherwiseinsecurity would increase overtime and become insurmountable.

Monetization of peace is a recipe for conflict resurgence.To ensure disagreeing parties do not elongate conflict for personnal gain, their bone of contention must be strategically resolved in such a way that each of the parties would want the conflict to end. In the case of the Niger Delta, Nigerian government played into the hands of the ex-militants. When oil production dropped from 2.4 million to 700,000 barrels per day at the heat of the militancy in 2008, Nigeria government was willing to do anything to save the nation's mono-product economy from collapsewithout considering the consequences (Agbiboa, 2015; Oluyemi, 2020). Clearly, thegovernment of Nigeria and the oil MNCs wanted the conflict to end in other to keep accruing profit, but the ex-militants have no such strong reason. Continuation of the conflict is what brings them income, either through the amnesty's largesse, or criminality.

For this reason, the ex-militants would not want the conflict to end because they are profiting from it. Some of them who are yet to get a job after training are surviving on the amnesty'slargesse and woulddo anything to keep the programme running for as long as possible.However, if Nigerian government had used the fundsspent on the programmeto provide infrastructure, the ex-militantswill want 
the conflict to end so that their community can experience more development.In the early years of its commencement, between 2009 and 2012, a massive N127 billion (US\$819) was assigned to the programme. N74 billion (US\$477 million) was allocated to itin 2012 (Ushie, 2013; Ajibola, 2015). These huge resources should have been used to tackle Niger Delta's environmental and developmental challenges - an action that would be of benefit to the whole population rather the youthcentred amnesty. Addressing the challenges could have eased the militancy since that was the militants' core reasons for perpetrating violence.

Since the amnesty programme is monetary based, government officials and non-state actors such as contractors and service providers woulddo all within their capacity to elongate the programme, or create violence that would necessitate the declaration of another amnesty. The appointment of ruthless ex-commanders as political office holders and contractors is both a means of steming the tide of the conflict, and sustaining it. The ex-commanders would not want the conflict to end since government's patronage - which is their new source of livelihood - depends on continuance of the conflict. Furthermore, the disbursement of money to persons whose only service to the nation is to stay off violence sends a wrong signal to decent citizens that violence is rewarding.

But then again, The N65,000 stipend being paid to the exmilitants monthly is measly, compared to what they were earning from violence -- a factor that may resurge the militancy. Pre-amnesty, the ex-militants often collect hundreds of thousands of dollars before oil workers held hostage are freed. Schmidle (2009) uncovered that oil MNCs in the Niger Delta paid over US\$100 million to secure the release of their abducted workers during the heat of the militancy between 2006 and 2008. Except Nigerian government pays the ex-militants something close to what they were earning before signing up for the amnesty programme (which is impossible), it would be difficult for them to desist from violence, even if they wish to. Their monthly stipend is too meagre to dissuade them from returning to violence. This is a challenge for the country.

First, the stipend cannot be sufficiently increased as doing so will hinder government from fulfilling its obligation to other sectors such as education. Secondly, government's monetization of the people's grievance is unsustainable. The ex-militants are being paid from the revenues generated on oil, a commodity that is limited and volatile. In addition, the amnesty is inhibiting broader engagement with other aggrieved persons. Aside the youths, other cadre of persons, especially women, children and the elderly have been left unattended to. Aside the Niger Delta, other regions facing security challenges -- such as Boko Haram terrorism in the Northeast -- may demand for amnesty and the benefits the Niger Delta youths enjoyed.

Evidently, paying for peace is unsustainable, especially after the unexpected depletion of revenues due to the drastic fall in global oil price after Covid-19 emerged. Even if the price of oil appreciates again, global demand for the commodity would reduce in the next years as the demand for rechargeable cars and reneweable energy increases. As revenue depletes, government's inability to promptly renumerate the ex-militant may bring back violence. Thus, other means of achieving sustainable peace such as eradicating environmental degradation, under-development, and providing an enabling environment where everyone can thrive according to their capacity, skills and expertise must be established.

Despite the peace understanding between Nigerian government and the ex-militants, soldiers continue to maintain an intimidatory presence is some parts of the Niger Delta. Although the soldiers mandate has changed from quashing a ruinous insurrection to securing oil installations and tacklingoil theft, innocent people suffer from their highhandednes daily. For instance, at every (unwarranted) checkpoint the authors passed through during fieldwork in the hinterland, soldiers were ordering people to disembark from their motorcycles (the most common means of transport in the rural areas) for no concrete reason. People had to push their motorcycles pass the checkpoints with the engine switched off. Putting people through such stress in a no-war situation is unnecessary. In addition, pushing the motorcycles was an uneasy task for people carrying goods as they have to either unload or push the motorcycle pass the checkpoints with the help of other travellers.

Furthermore, the soldiers are fond of dehumanizing people at the slightest altercation. This needless intimidationis causing disenchantmentsthat may transmute into conflict someday, perhaps soon.High-handedness is a feature of the military, while extortion is an attribute of the police. Transporters are brazenly extorted onthe highways and failure to comply often results intoharassment and brutality. To eradicate the immoderations of the security agencies and enhance the safety of lives and properties, Ushie (2013) asserts that Nigerian government needs to consider the ex-militants, community leaders, youth groups, and civil societies as important partners in security matters and get them actively involved in the protection their communities.

\section{CONCLUSION}

The amnesty programme should be a first instrument of conflict resolution, and not the final, as the lack of further major action by Nigerian government since 2009 is making itappear to be. The inaction is a pointer that the amnesty programme was mainly instituted to ensure unhindered exploitation of oil and gas resources in the Niger Delta.Nevertheless, the programme is a commendable departure from Nigerian government's typical hard approach to tackling conflict, which often aggravate tensionrather than eradicate it. The soft approach, amnesty, has effectively stemmed the tide of violence in the Niger Delta. However, Nigerian government's monetization of the programme makes it unsustainable as the ex-militants rescind from violence 
based on financial enticement, not out of personnal conviction. Once the instrument of enticement (money) is no longer available, the ex-militants would most likely return to violence. For instance, they returned to violence when their stipends was delayed in 2016 and retreated after they were paid in arrears.

If urgent actionis not taken, the propability of violence reoccurring is quite high as the environmental, social and developmental issues that triggered the militancy are yet to be addressed. Addressing these issues largely determines how cordial Niger Delta populaces' relationship with Nigerian governement and the oil MNCs would be. It also determines the future of oil operations in the region. The plights of the people must be swiftly addressed as the reward of maintaining a good relationship with them outweighs the gains of having a strained one. If Nigerian government and the oil MNCs have a good relationship with the Niger Delta populace, both will experience unhindered oil operation and make huge profit for years. But if they have a strained relationship with the populace, they may still make profit if force is applied, but it will be for a short term; before the conflict escalates. The gains of having a good relationship with the host communities outweighs that of having a strained relationship with them. Hence, the oil MNCs must independently strive to make their relationship with their host communities cordial. The amnesty's potency to institute lasting peace in the Niger Delta is dependent on Nigerian government and the oil MNCs ability to address the substantive operational, developmental, economical and environmental issues in the region. Failure to address these issues would generate violence at some future time.

\section{REFERENCES}

[1] Adeosun, A.B., Ismail, N., Zengeni, K.T. (2016). Elites and conflict in Nigeria: A case study of the Niger Delta insurgency. Inter. J. Polit. Sci. Develop., 4(8), 301-314.

[2] Agbiboa, D. E. (2015). Transformational strategy or gilded pacification? Four years on: The Niger Delta armed conflict and the DDR process of the Nigerian amnesty Programme. Journal of Asian and African Studies, 50(4), 387-411.

[3] Aghedo, I. (2012). Winning the war, losing the peace: Amnesty and the challenges of post-conflict peace-building in the Niger Delta, Nigeria. Journal of Asian and African Studies, 48(3), 267280.

[4] Aghedo, I. (2015). Sowing peace, reaping violence: Understanding the resurgence of kidnapping in post-amnesty Niger Delta, Nigeria. Insight on Africa, 7(2), 137-153.

[5] Ajayi, A. I., \&Adesote, A. S. (2013). The gains and pains of the amnesty programme in the Niger Delta region of Nigeria, 20072012: A preliminary assessment. Journal of Asian and African Studies, 48(4), 506-520.

[6] Ajibola, I. O. (2015). Nigeria's amnesty programme: The role of empowerment in achieving peace and development in postconflict Niger Delta. SAGE Open, 5(3), 1-11.

[7] Akinwale, A.A. (2010) Amnesty and human capital development agenda for the Niger Delta. Journal of African Studies and Development, 2(8), 201-207.

[8] Austine, E.,\& Sunday, E. (2013). Niger Delta: A critical appraisal of the amnesty programme and social political development in Nigeria. Research on Humanities and Social Sciences, 3(22), 130137.
[9] Bodo, T. (2020). Illegal oil bunkering in the Niger Delta region of Nigeria: A challenge to Nigeria's development. European Scientific Journal, 16(29), 1857-7881.

[10] Campbell, J. (2015). A primer on Nigeria's oil bunkering. Council on Foreign Relations.

[11] Douglas, O., Kemedi, V., Okonta, I., \& Watts M. (2003). Oil and militancy in the Niger Delta: Terrorist threat or another Colombia? Economies of violence, working paper No. 4

[12] Eke, S. J. (2014). No pay, no peace: Political settlement and postamnesty violence in the Niger Delta, Nigeria. Journal of Asian and African Studies, 50(6), 750-764.

[13] Ekumaoko, C. E. (2013). The amnesty question in post conflict Niger Delta and peace-building. Arabian Journal of Business and Management Review, 2(10), 1-12.

[14] Emuedo, C. (2010). Politics of conflict, oil and petro-violence in the Niger Delta. Global Journal of Social Sciences, 9, 73-81.

[15] FGN: Federal government of Nigeria (2009). Presidential Amnesty for Militants in the Niger Delta region. Nigeria.

[16] Golden-Timsar, R. (2018). Amnesty and new violence in the Niger Delta. University of Houston Energy Fellows.

[17] Hazardex (2019). New report finds Nigeria has lost $\$ 42 \mathrm{bn}$ to crude oil theft in last decade.Hazardex Press

[18] Hinshaw, D. (2012). Niger Delta amnesty programme fails to end militancy. The Wall Street Journal.

[19] Human Rights Watch (2003). The Warri crisis: Fueling violence. HRW, 15(18A).

[20] Ibaba, I.S (2011). Amnesty and peace-building in the Niger Delta: Addressing the frustration-aggression trap. African, 5(1), 238-271.

[21] International Crisis Group. (2008). Nigeria: Ogoni land after Shell. Crisis Group Africa Policy Briefing 54.

[22] Saro-Wiwa, K. (1994). Ogoni moment of truth. Saros Int. Publishers, Port Harcourt.

[23] Koos, C. (2017). Which grievances make people support violence against the State? Survey evidence from the Niger Delta. Empirical and Theoretical Research in International Relations, 44(3), 437-462.

[24] Kuenzer, C., Beijma, S., Gessner, U., \&Dech, S. (2014). Land surface dynamics and environmental challenges of the Niger Delta, Africa: Remote sensing-based analyses spanning three decades (1986 -2013). Applied Geography, 53, 354-368.

[25] Mai-Bornu, Z., \&Ladan, Z. (2020). Political violence and oil in Africa - The case of Nigeria. Switzerland: Palgrave Macmillan.

[26] Nwozar, A. (2010). A Delta of minefield: Oil resource conflict and the politics of amnesty in Nigeria. Conflict Trends, 1, 28 - 35.

[27] Odera, O., Scott, A., \&Gow, J. (2018). Community perceptions of Nig. oil companiescommitment to social and environmental concerns. Journal of Global Responsibility, 9(1), 73-95.

[28] Ogege, O. S. (2011). Amnesty initiative and the dilemma of sustainable development in the Niger Delta region of Nigeria. Journal of Sustainable Development, 4(4).

[29] Ojakorotu, V. (2011). Anatomy of the Niger Delta crises: Causes, consequences, and opportunities for peace. Piscataway, NJ: Transaction Publishers.

[30] Okeke-Ogbuafor, N., Gray, T. S, \& Stead, S. M. (2018). Perceptions of the existence and causes of structural violence in Ogoni communities, Nigeria. Journal of Contemporary African Studies, 36(2), 229-244.

[31] Okonkwo, C. N., Kumar, L., \& Taylor, S. (2015). The Niger Delta wetland ecosystem: What threatens it and why should we protect it? African Journal of Environmental Science and Technology, 9(5), 451-463.

[32] Okonofua, B. A. (2016). The Niger Delta amnesty program: The challenges of transitioning from peace settlements to long-term peace. SAGE Open, 6(2), 1-16.

[33] Olaniyi, O. O. (2011). Post-amnesty program in the Niger Delta: Challenges and prospects. Conflict Trends, 4, 46-54.

[34] Oluwaniyi, O. O. (2018). The role of multinational oil corporations in Nigeria: more exploitation equals less development of oil-rich Niger Delta region. Review of African Political Economy, 45(158), $558-573$. 
[35] Oluyemi, O. (2020). The military dimension of Niger Delta crisis and its implications on Nigeria national security. SAGE, 10(2), 113.

[36] Omojimite, B. U. (2012). Sustainable development, peace and security in the Niger Delta region. European Journal of Social Sciences, 28, 549-558.

[37] Osha, S. (2006). Birth of the Ogoni protest movement. Journal of Asian and African Studies, 41(1-2), 13-38.

[38] Schmidle, N. (2009). The hostage business. The New York Times Magazine.
[39] Ubhenin, E. O. (2013). The Federal Government's amnesty programme in the Niger-Delta: An appraisal. YönetimBilimleriDergisi, 11(21), 179-203.

[40] Ushie, V. (2013). Nigeria's amnesty programme as a peacebuilding infrastructure: A silver Bullet? Journal of Peacebuilding and development, 8(1), 30-44.

[41] Watts, M. (2004). Resource curse? Governmentality, oil and power in the Niger Delta. Geopolitics, 9(14), 50-80. 